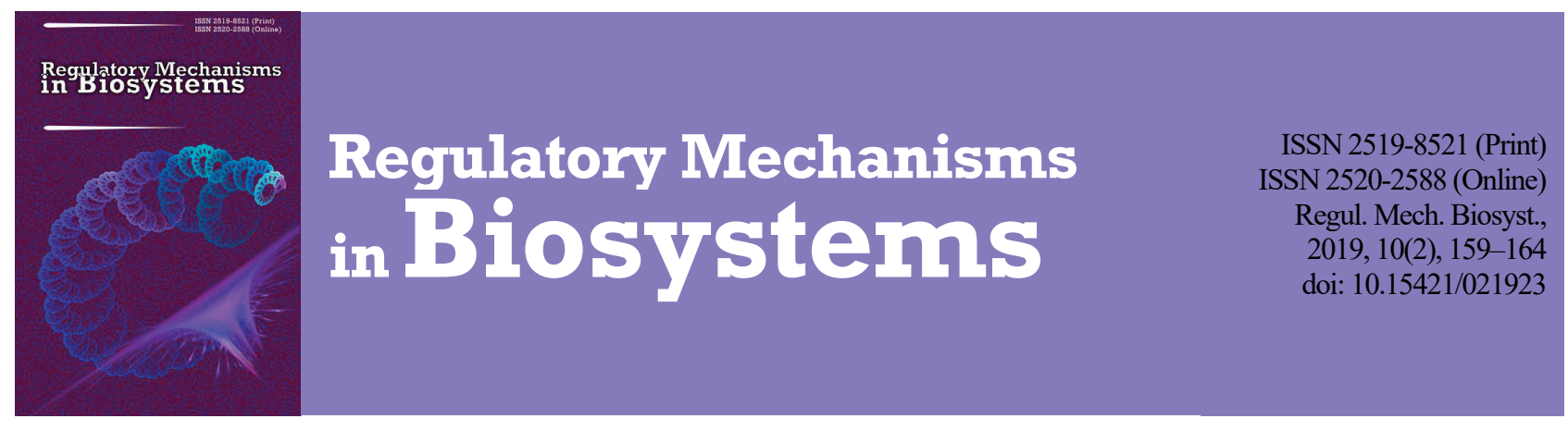

\title{
Ontogenesis of Pelargonia sidoides (Geraniaceae) under greenhouse conditions
}

\author{
M. M. Gaidarzhy, A. V. Holubenko, N. V. Nuzhyna, O. A. Futorna, O. O. Senchylo \\ Taras Shevchenko National University of Kyiv, Kyiv, Ukraine
}

Article info
Received 28.04 .2019
Received in revised form
22.05 .2019
Accepted 23.05 .2019

Taras Shevchenko

National University

of Kyiv, S. Petliura st., 1

Kyiv, 01032, Ukraine.

E-mail:

gaidarzhy@ukr.net

\author{
Gaidarzhy, M. M., Holubenko, A. V., Nuzhyna, N. V., Futorna, O. A., \& Senchylo, O. O. (2019). Ontogenesis of Pelargonia sidoides \\ (Geraniaceae) under greenhouse conditions. Regulatory Mechanisms in Biosystems, 10(2), 159-164. doi:10.15421/021923
}

The article presents the results of the ontogenesis study and complements the morphological description of the valuable medicinal plant Pelargonium sidoides, which is included in the Red List of Plants of South Africa, from the collection of succulents of the O. V. Fomin Botanical Garden. Unlike some species of the Pelargonium genus, which are stem succulents, P. sidoides is a succulent with thickened roots. It has been established that the pregenerative period lasts about 10 months, while the longest is the juvenile stage, during which plants form a large leafy series and begin to form thickened roots. The seedling stage in $P$. sidoides is much shorter than in many stem succulents with non-succulent leaves. Plants are cross-pollinated, in the conditions of cultivation they form a peduncle longer than in nature, up to $90 \mathrm{~cm}$ in length. Flowers are open to 6 days and during this time they undergo three consecutive stages: the opening of the anthers, an asexual pause, readiness of the pistil to be pollinated. Pollen grains are typical for representatives of the Pelargonium genus, but smaller, compared to pollen representatives of other sections. Fruits ripen in a short period 17-25 days, depending on the air temperature. The mericarps of $P$. sidoides differ in shape, colour and size from the mericarps of representatives of other genera of the Geraniaceae family, but the morphological characteristics of the seeds within the family are similar. The germ is located on the abdominal side of the seed; it occupies almost half of its volume and has clear outlines. According to its morphological features, $P$. sidoides leaves, as in most other species of the genus, have both mesomorphic and xeromorphic features. Analysis of the data gives ground for characterizing these plants as meso-xerophytes. $P$. sidoides quickly enters the generative period in the conditions of greenhouse cultivation and has high reproductive capacity.

Keywords: ontogenesis; seeds; flowers; pollen; leaves; leaf anatomy.

\section{Introduction}

The Geraniaceae family includes about 750 species which belong to 11 or 4 genera, depending on the author. The two largest genera are Geranium Linnaeus (includes over 300 species, the representatives are mostly distributed in moderate climates) and Pelargonium L'Heritier ex Aiton (includes about 280 species, representatives are distributed in tropical and subtropical areas of the world) (Albers, 2002).

Plants of the Pelargonium genus are common in Madagascar, Turkey, Yemen, Australia but most of the species (90\%) grow in South Africa. By growth form, the plants are usually shrubs, subshrubs or herbaceous plants; geophytes or xerophytes. According to Albers (2002), almost $50 \%$ of representatives of the genus are succulent plants and are caulescent or root succulents. According to modern data, based on morphological peculiarities of the plants and results of molecular-genetic analysis, the genus is divided into 17 sections, 13 of which contain succulent species.

Genus Pelargonium plants are widely known as decorative flower plants. In exterior landscape gardening the most widely used are the blended hybrids of two species: P. zonale (Linnaeus) L'Heritier and $P$. peltatum (Linne) L'Heritier ex Aiton. For interior landscaping in moderate climates and exterior in subtropical and tropical climates, $P$. grandiflorum (Andrews) Willd hybrids, also known as English pelargoniums, are popular. They feature relatively large multi-coloured flowers, bundled into multi-flower inflorescences (Shirokova, 2006).

Plants and hybrids of $P$. graveolens L'Heritier and $P$. incrassatum (Andrews) Sims (sin. P. roseum (Andrews) Aiton) are used to produce geranium oil, used in perfumery products. For this purpose they are grown in many tropical countries, such as India, Bangladesh, Egypt, Madagascar etc. However, some representatives of the genus have been known as medicinal plants among the peoples of South Africa since historic times. Roots and/or leaves of over 10 species of pelargoniums, including $P$. graveolens, $P$. peltatum and $P$. zonale are used for treating quite a broad range of ailments such as liver, kidney and digestion disorders, respiratory illnesses, for wound treatment etc. Modern studies have shown potent antibacterial, antifungal and acaricidic properties of the geranium essential oil obtained from the aforementioned and several other species of pelargoniums (Pirami-Kheirabadi et al., 2010; Kolodziej, 2011; Carmen \& Hansu, 2014).

In the last decades, researchers have paid particular attention to two species: P. sidoides De Candolle and P. reniforme Curtis. In Europe, the extract from $P$. sidoides roots called EPs7630 was first used in Germany in the 1980s. It was based on the on the plant preparation used in traditional medicine of such peoples as the Zulu, Xhosa and Basotho of South Africa, caled Umckaloabo, Kalwerbossie, and Zucol. Further clinical research has shown the efficiency of the drug in treating respiratory infections, acute bronchitis and pneumonia. Nowadays, plants of the species are grown on farms in South Africa and Lesotho (Brendler \& van Wyk, 2008; Mthiyane et al., 2016).

The biochemical content of the geranium oil of various Pelargonium species, accumulated in leaf surface trichomes has been studied quite well - about 230 components are determined. Among them are derivatives of monoterpenes and sesquiterpenes, flavonoids, derivatives of salicylic acid, phenolic acids, tannins, essential oils, etc. Large amounts of biologically active substances, such as phenolic and polyphenolic compounds, coumarins and tannins have also been found in the bulbous roots of $P$. sidoides and P. reniforme (Matthys et al., 2003; Shellie \& Marriott, 2003; Saraswathi et al., 2011; Mayo \& van Staden, 2014).

Most of the succulent pelargoniums are included in the Red List of South Africa (Red List..., 2009). Among the above mentioned pelar- 
gonium species, the following are included in the LC (Least Concern, minimum risk) category of the List: $P$. graveolens, $P$. incrassatum, $P$. zonale, $P$. peltatum; $P$. reniforme, placed in the DDD category (Data Deficient - Insufficient Information). It should be noted that increased interest in medicinal raw materials and decorative plants might rapidly move certain species to higher categories. Besides, another factor causing the decrease of the plants' populations is the arid environment in which their reproduction and growth are limited to the wet season.

The succulent plant collection at the O. V. Fomin Botanical Garden includes 8 species of pelargoniums: P. carnosum (Linnaeus) L'Heritier, $P$. ceratophyllum L' Heritier, $P$. crassicaule L'Heritier, $P$. crithmifolium J. E. Smith, P. echinatum Curtis, $P$. gibbosum (Linnaeus) L'Heritier, $P$. sidoides De Candolle, and $P$. tetragonum (Linnaeus fil.) L' Heritier, which are representatives of both stem and root succulents. In total, the collection includes representatives of five sections, gathered through the years. For instance, $P$. tetragonum has been grown for over 60 years, and $P$. gibbosum - for only three years. Most of the species are distributed throughout the western regions of South Africa, but $P$. sidoides originates from central and eastern regions of the country. All of the succulent pelargoniums present in the collection have been included to the Red List of South African Plants in the LC category, with the exception of $P$. sidoides, included to the collection in 2014. Plants of this species are somewhat different from other pelargoniums by morphological features and are one of the few succulents, actively used as medicinal raw material. In order to develop a technique of growing $P$. sidoides under greenhouse culture conditions, the ontomorphogenetic peculiarities and reproductive ability of the species must be studied, which became the objective of our study.

\section{Materials and methods}

The plants were identified using several sources (Dreyer \& Marais, 2000; Albers, 2002; Brendler \& van Wyk, 2008). Latent and pregenerative periods of ontomorphogenesis of $P$. sidoides plants in protected premises (greenhouses of the O. V. Fomin Botanical Garden) were investigated. The plants were grown in succulent mode, in a soil mix specifically prepared for succulents (Shirobokova et al., 2003).

The research material consisted of seeds, generative and vegetative parts of $P$. sidoides plants. Flowers and fruits were described by atlases (Fedorov \& Artyushenko, 1975; Artyushenko \& Fedorov, 1986). Seeds were described using generally excepted terminology (Barthlott, 1984; Gontcharova et al., 2006). For anatomical studies, the middle part of the leaf blade was used. The samples were fixed in the following chemical mixture: 5 parts of formalin, 5 parts of glacial acetic acid, 90 parts of $70 \%$ ethanol, and cast in gelatin using the standard technique (Ilinska et al., 2001); next, using the OMT-28-02E (KB-Technom, Russia) freezing microtome, cross sections $10-15 \mu \mathrm{m}$ thick were made. Taking into account the changes to mesophyll structure and projections of epidermis cells in different parts of the plant, fragments of the leaf from the middle parts of the length were always used for the studies. The samples were dyed with a weak safranin solution. The epidermis was additionally studied under a scanning microscope. The anatomical features of the leaves and stems were described by methods developed by Vasiliyev (1988) and Zakhare$\operatorname{vych}(1954)$.

In addition, glycerine microsections of pollen grains were prepared for studies under an optical microscope; the grains were dyed with safranin for studies of the exine structure and thickness. The studies were conducted using a Carl Zeiss (PrimStar) optical microscope with Scope Tek (Etrek DCM 510) camera and an Olympus System Microscope ModelBX41 (Japan). For topology studies of the pollen grains under the scanning microscope (CEM, JSM 6060 LA), they were fixed on brass surface in $96 \%$ ethanol and sprayed with a layer of gold by standard technique. The pollen grains were described using common terminology (Tokarev, 2002). The measurements were performed with AxioVision 8.0 software.

\section{Results}

P. sidoides is a herbaceous plant with shortened stalks and thickened roots. The leaves are gathered into a multi-leaf rosette (Albers,
2002). The leaf blade is simple, greyish-green in colour; the shape varies from oval-heart-shaped to kidney-like with rounded edges and weakly expressed cantles. The width of the blade lies within $5.5-7.5 \mathrm{~cm}$, length $4-6 \mathrm{~cm}$. The petiole is $15-20 \mathrm{~cm}$ long. The leaf blade is densely covered with trichomes (Fig. 1).

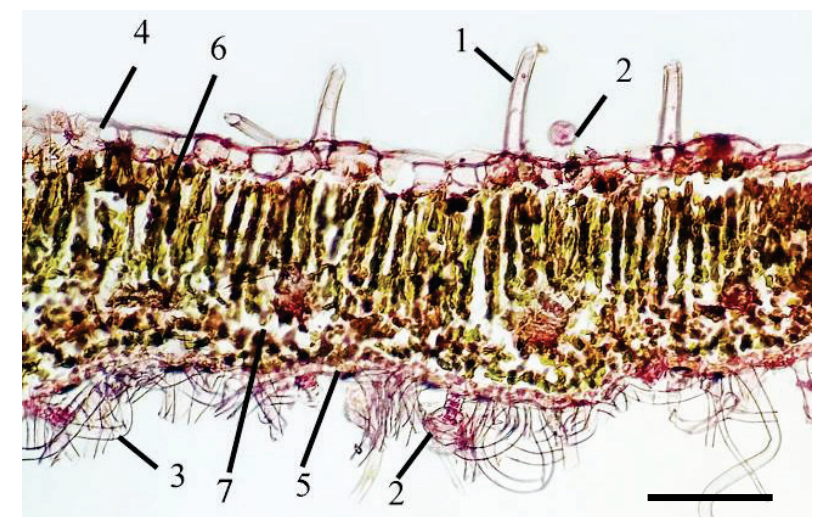

Fig. 1. Cross section of Pelargonium sidoides leaf blade: 1 - non-glandular trichomes on the adaxial side of the leaf;

2 - glandular trichomes; 3 - non-glandular trichomes on the abaxial side of the leaf; 4-adaxial epidermis; 5 - abaxial epidermis;

6 - palisade parenchyma; 7 - spongy parenchyma; bar- $100 \mu \mathrm{m}$

The leaves are amphistomatic, the stomates - anisocytic, located on the same level with the main epidermis cells. The adaxial epidermis of the studied species is aristate. In the paradermic plane the epidermis cells are characterized as follows: over the mesophyll - by cells with flattened projections and curly shapes, in the conductive bundle regions by elongated projections, with shapes ranging from curly to straight. The cuticle ranges from smooth to striatal; rarely - epicuticular wax can be found on it, represented by rough-edged crystals (Fig. 2c). On the top surface of the leaf, scattered indumentum is present, formed by two types of trichomes - multi-cell hooked trichomes with long distal cells, which have warty surfaces and are $100 \mu \mathrm{m}$ long, and small glands with a two-cell stalk and single-cell head (Fig. 2c). For the studied species, the adaxial and abaxial surfaces are different. They feature felt-like downiness, formed by long stripe-like trichomes up to $300 \mu \mathrm{m}$ long, short hooks and glands (Fig. 2a,b). The epidermis tissue is single-layered, formed by thin-walled cells. The top epidermis is better developed and is twice as thick as the bottom one $(19.49 \pm 0.58$ and $8.00 \pm 0.37 \mu \mathrm{m}$, respectively) (Fig. 1). On the cross section, the shape of epidermis cells on the same side of the leaf varies from roundish-elongated (under and over mesophyll) to round (under and over the costa). Cells of the epidermis on the adaxial surface are somewhat wider and have thicker external walls, compared to the lower epidermis cells, which are roundshaped and have thin external periclinal walls.

On the cross section, the leaf blade is elongated in a horizontal direction and a well distinguished round carina can be seen under the costa. The blade is $168.1 \pm 5.2 \mu \mathrm{m}$ long and can be called thin. The mesophyll is dorsoventral, $139.6 \pm 6.3 \mu \mathrm{m}$ thick. The palisade parenchyma is located on the top side of the leaf and is represented by two very dense layers of extremely long cells (elongation factor is 3.3). The conductive system is represented by a central and 18 to 20 side conductive bundles. The bundles do not include any mechanical tissue and slightly vary in size. Only the central conductive bundle has a chlorophyll-free cover. Epidermis cells and phloem contain essential oils, while the chlorophyll-free parenchyma contains both essential oils as well as druses of calcium oxalate.

The peduncle is complex, containing 4 to 10 (25) lateral inflorescences about $95 \mathrm{~cm}$ long; it is first orientated vertically, but with age takes a horizontal position (lies down), which is also common for other South African plants (Gajdarzhi, 2003). Flowers have pedicels, are up to $4 \mathrm{~cm}$ long; 4 to 7, more often 6 flowers are grouped in a compound umbel. There are 5 sepals, green, with a white edge. The flowers are zygomorphic, bisexual, with dark red or dark purple narrow petals, or wider dark red petals (Dreyer \& Marais, 2000). The two upper petals are 
larger than the lower ones. The androecium is uneven, consists of 7 stamens of different lengths; pollen is bright yellow, stalk of stamen is strictly vertical.

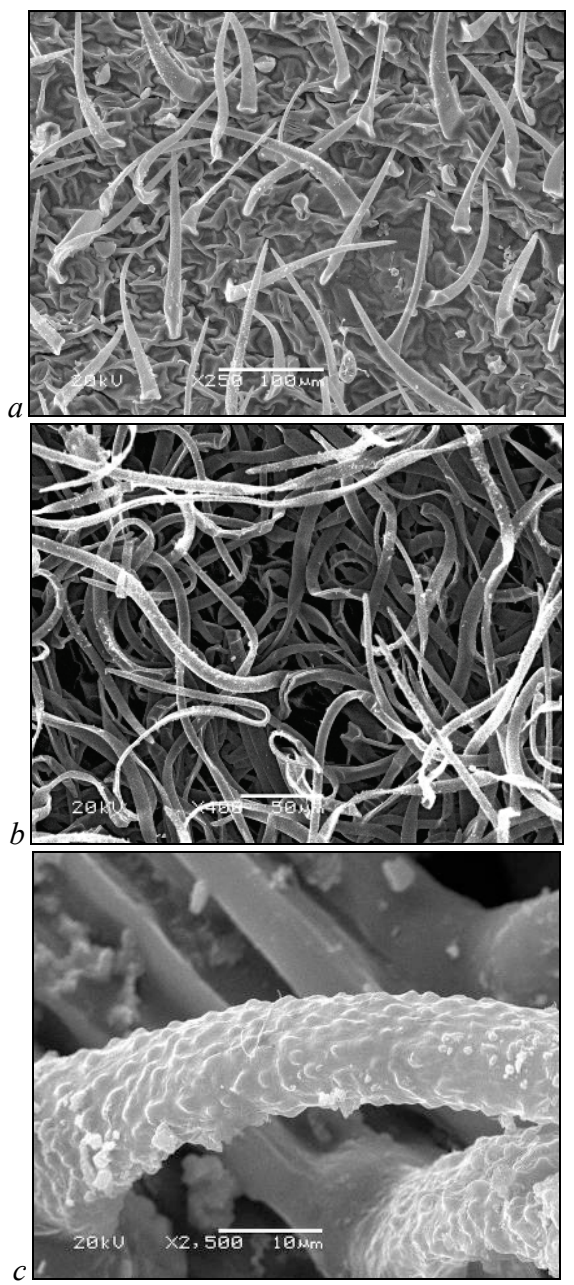

Fig. 2. Trichomes of Pelargonium sidoides leaves: $a$-non-glandular and glandular trichomes on the adaxial epidermis; $b$-non-glandular trichomes on the abaxial epidermis; $c$ - warted surface of multi-cellular trichomes and traces of epithelium wax on the adaxial epidermis

Pollen grains are spheroid (shape index of 0.96), tricolpate. If viewed from the poles - the shape is vaguely three-blade and from the equator - elliptical to round. The grooves are long, 2.0-5.3 $\mu \mathrm{m}$ in length, have well-defined margins and become narrower downward to the sharpened edges. The membranes, which the grooves are covered with, are granular. The surface topology of the pollen grain is reticular on the proximal side and between the grooves. The exine is $1.1-1.7 \mu \mathrm{m}$ thick, without any noticeable increase in thickness near the aperture edges. Pollen grain diameter in the polar plane ranges (19.9) 22.6-35.9 (37.2) $\mu \mathrm{m}$, and in the equatorial - 20.4-21.8 $\mu \mathrm{m}$ (Fig. $3 a, b, c$ ).

Flowers within the inflorescence open one by one in one of the following orders: $1+1+2+2$ or $2+1+1+2$. Florescence lasts up to 6 days and consists of 3 stages. The first stage is male - during the opening of the flower, the anthers are open and pollen is suitable for pollination. The second stage, lasting 1-2 days, can be considered asexual, when almost all of the pollen is gone but the pistil is not yet ready to accept pollen. On the fifth day, the stigma pistil opens and the flower can be pollinated. On the sixth day (or at the end of the 5th), the pistil still can accept pollen, but the petals of the flower have partially fallen off. Such scenario of flower development indicates the entomophilous adaptation of $P$. sidoides to cross-pollination.

The ovary is of the superior type and has 5 locules, with one embryo per locule. The fruit is a type of capsule and is called a sterigma, which has a column formed by a sterile part of carpophylls, near which 5 mericarps with appendices are located (Artyushenko \& Fedorov,
1986). Maturation of the fruits occurs during 17-25 days, depending on the outside temperature. We have noted the appearance of vegetative buds on the peduncles during the fall.

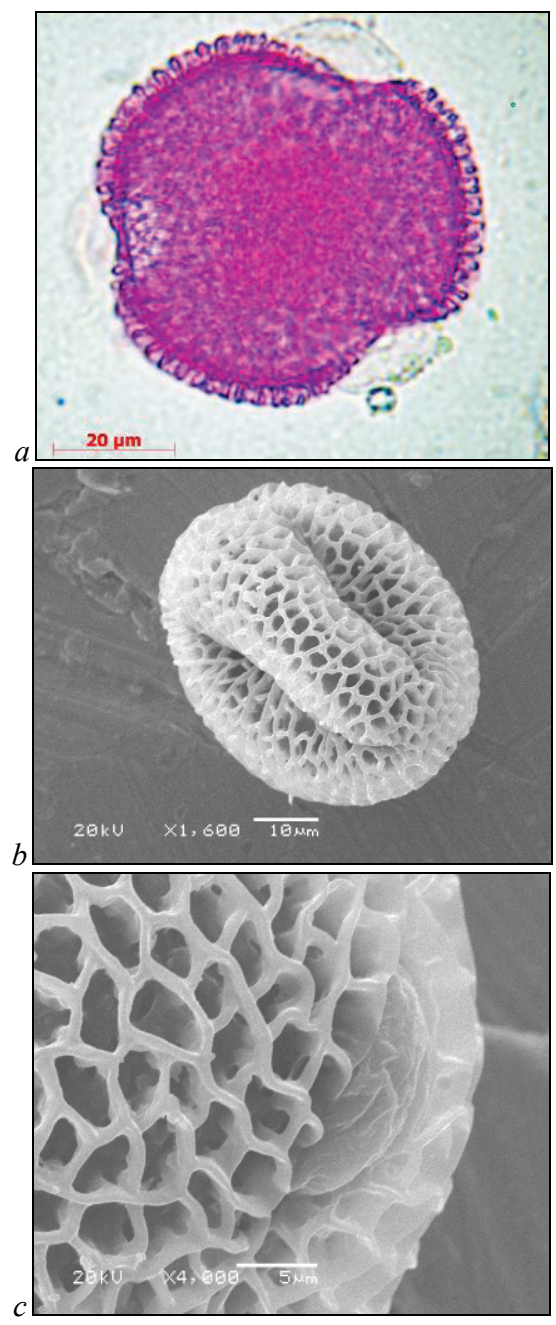

Fig. 3. Pollen grain of Pelargonium sidoides: $a$-scanning microscope image of pollen grain; $b$-scanning electron microscope image of pollen grain; $c$ - pollen grain surface topology

Latent period. During maturation of the seeds, mericarps of $P$. sidoides become completely separated from the column. The mericarp, 4.5-5.0 mm long and 2.0-2.5 mm wide in the widest part, is fusoid, downy, greyish-brown, has a gap on the inside surface. The axial appendix is about $15 \mathrm{~mm}$ long, its middle part - curled and has bundles of lightly coloured fibers (Fig. 4). The seeds either remain in the mericarp, or, with a little force applied, can fall out through the gap.

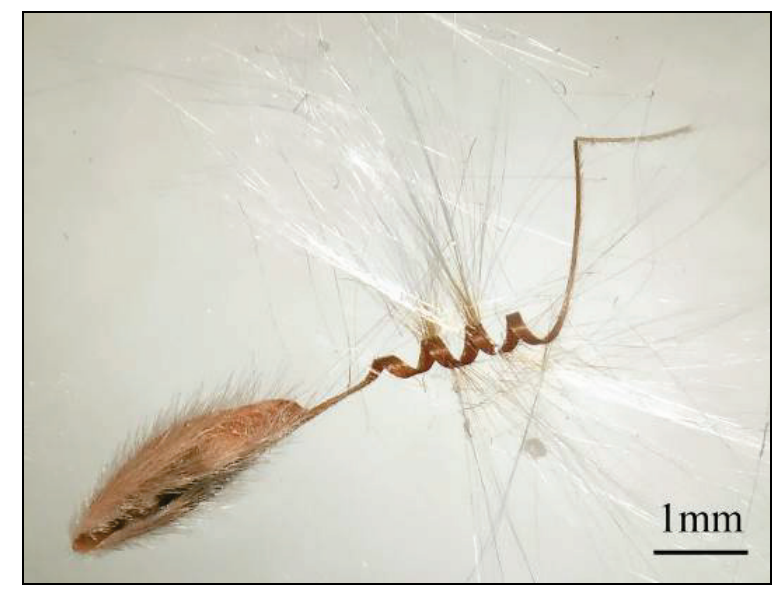

Fig. 4. Mericarp of Pelargonium sidoides 
The seeds are campylotropous, which is caused by bending of the embryo sac, and, as a consequence - the embryo has a thickened region of the inner integument on the side of the raphe. This thickened part is formed as a result of periclinal division and elongation of the middle layers of the inner integument (Sravnitel'naya..., 2000). Hypocotyl with the embryonic root and cotyledon are well defined. The seed coat is mat black; the seeds are bare, $2.91 \pm 0.16 \mathrm{~mm}$ long, $1.33 \pm 0.10 \mathrm{~mm}$ wide, $1.07 \pm 0.06 \mathrm{~mm}$ thick. Mass of 1,000 seeds is $1.90 \mathrm{~g}$.

Seeds of the studied plants are inverse lance-shaped, almost cylindrical; the back of the seed is straight, the ventral part - slightly swollen and somewhat elongated in the micropyle region (Fig. $6 a$ ). The cross section is elliptical.

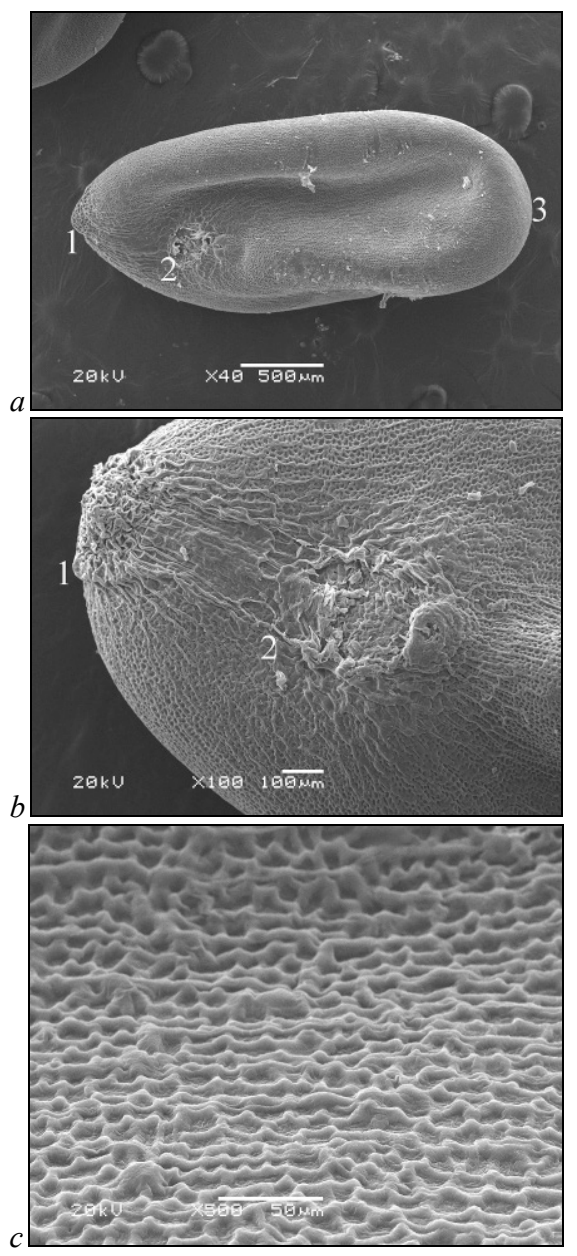

Fig. 5. Seed of Pelargonium sidoides: $a$ - seed, abdominal side; $b$ - micropyle region; $c$ - surface topology; 1 - hilum, 2 - micropyle

The hilum is distinct, not sunken, round-shaped, sub-basal (goes up from the base of the seed), consists of convex cells, which are larger in size and lighter in colour than other cells of the testa of the seed (Fig. 5b, 6b). The cuticle is wrinkled, well-developed. Testa cells are polygonal, with well-defined borders. Periclinal walls of the cells of the seed coat are concave. Anticlinal cell walls are always uniformly thickened and straight. The surface is pitted (Fig. 5c).

The embryo fits closely to the seed coat on the abdominal side of the seed. It is located in the upper region, lateral to the vertical axis and takes about half of the seed's volume. The embryo is spade-shaped, about $1.5 \mathrm{~mm}$ long and up to $0.7 \mathrm{~mm}$ wide. The endosperm is lightgreen (Fig. 6a).

Pre-generative period. Germinant stage. Germination occurs underground. Germinating ability of freshly collected seeds is $66 \%$. Over a year of being stored in laboratory conditions, the ability slightly decreases. At $24-27^{\circ} \mathrm{C}$, the seeds germinate on the 3rd day. After being stored for over 6 months - on the 4-5th day. At first, the main root (Fig. $6 b$ ) appears, then - the hypocotyl and cotyledons, sized under $1 \mathrm{~mm}$, emerge to the surface.

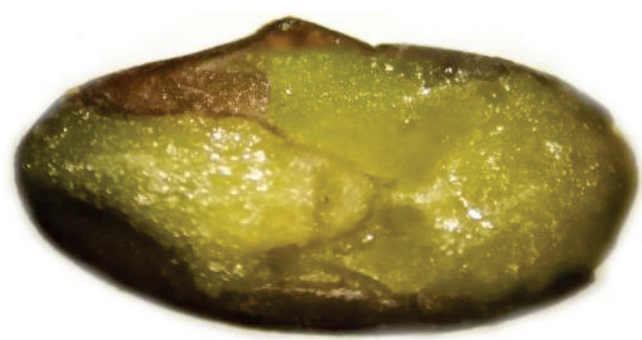

$a$

$200 \mathrm{mkm}$

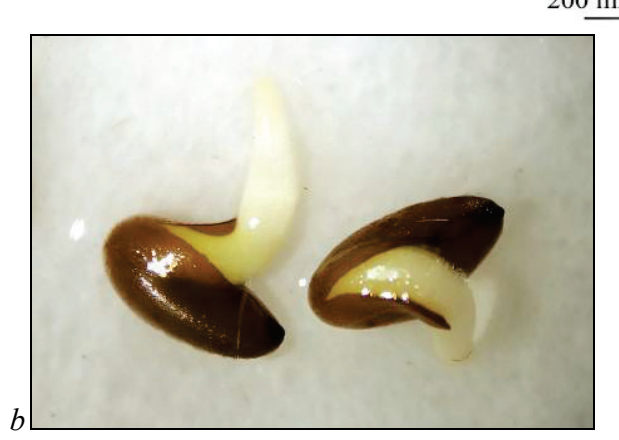

Fig. 6. Seed and first-day germinant of Pelargonium sidoides: $a$-cross section of the seed; $b$-beginning of the germination of the seed

On the fifth day after germination, the germinant has two differently sized cotyledons, covered in singular trichomes. The cotyledons are round-shaped, the larger being $0.65 \pm 0.05 \mathrm{~mm}$ and the smaller $-0.45 \pm$ $0.06 \mathrm{~mm}$ long. The hypocotyl reaches $20 \mathrm{~mm}$ in length (Fig. 7). The first true leaf appears on the 7-9th day.

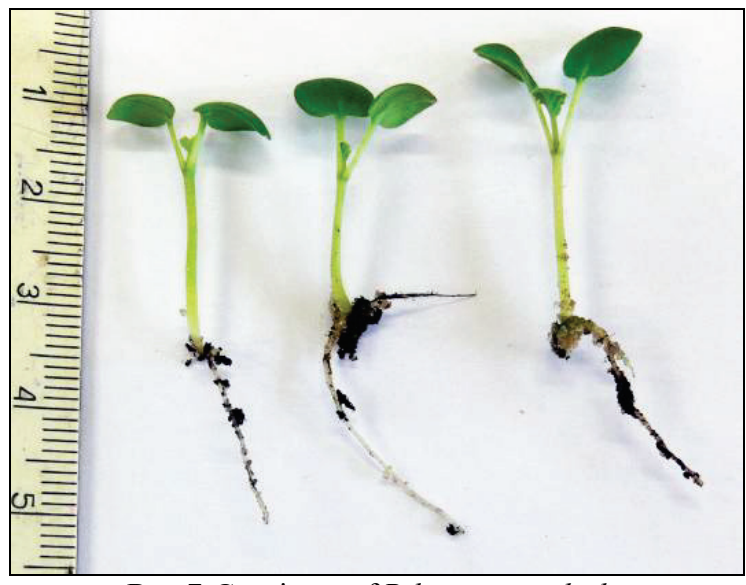

Pис. 7. Germinants of Pelargonium sidoides on the fifth day of germination

Pre-generative period. Juvenile stage lasts for 6 months, during which the plants form 17-25 leaves, creating a rosette. Each consecutive leaf has a blade larger than the previous one, increasing from $13.4 \pm$ $0.05 \mathrm{~mm}$ in length and $15.7 \pm 0.04 \mathrm{~mm}$ in width, with the petiole being about $17 \mathrm{~mm}$ long, to $53.0 \pm 0.4 \mathrm{~mm}$ long and $61.0 \pm 0.6 \mathrm{~mm}$ wide, with the petiole being about $16.5 \mathrm{~mm}$ long (Fig. 8a). Heterophylly was not in observed. The cotyledons die off during the second month of the development of the plant; the hypocotyl part of the stem increases to $30 \mathrm{~mm}$ long and $4 \mathrm{~mm}$ in diameter and is clearly seen during the entire pre-generative period.

Formation of thickened roots in the studied plants starts on the second month of their development. At the age of 2 months, the main root or 1-2 additional ones have thickened regions up to $15-20 \mathrm{~mm}$ long and $3 \mathrm{~mm}$ in diameter (Fig. $8 b$ ). After 4 months of the development, the thickened region grows to $20-25 \mathrm{~mm}$ long and $4-8 \mathrm{~mm}$ in diameter; at the same time, additional lateral thickened roots appear. Next, active increase in thickness of roots takes place, which reach $9 \mathrm{~mm}$ in diameter at 6 months of age.

Pre-generative period. The virginile stage lasts 3-4 months for $P$. sidoides. During this period, some of the lower leaves of the rosette 
die off and the plant is left with 12-17 leaves, the blades of which reach the size, typical for that of generative period of the species. The diameter of the bulges on the roots increases to $10 \mathrm{~mm}$ and additional roots, 5-7 $\mathrm{mm}$ in diameter appear (Fig. 9a,b).

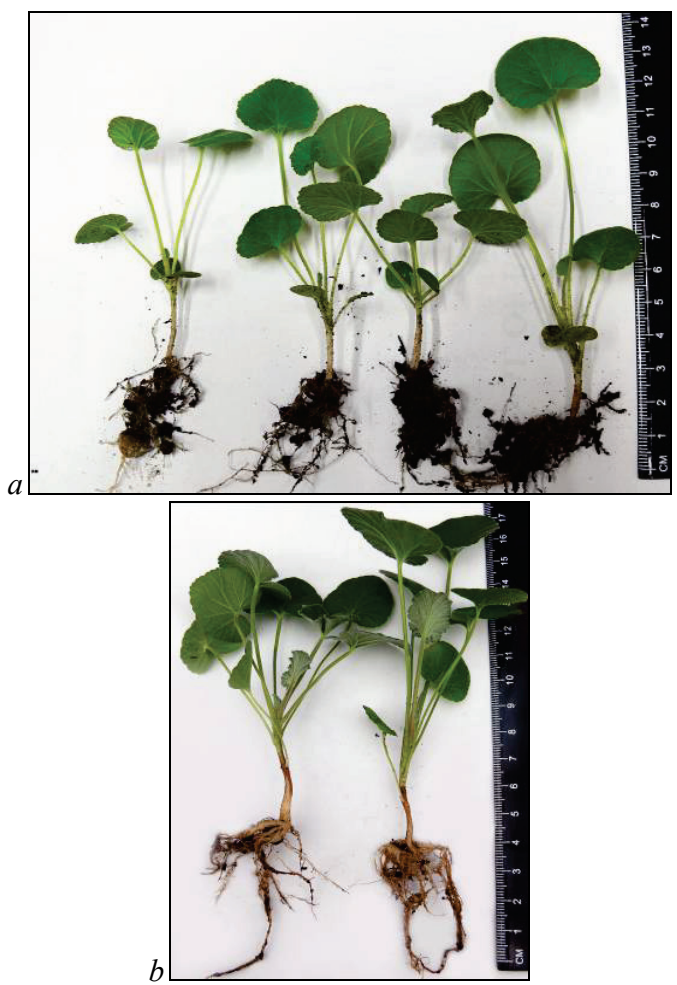

Fig. 8. Beginning of the juvenile development stage of Pelargonium sidoides: $a$-one month-old plants; $b$ - two month-old plants
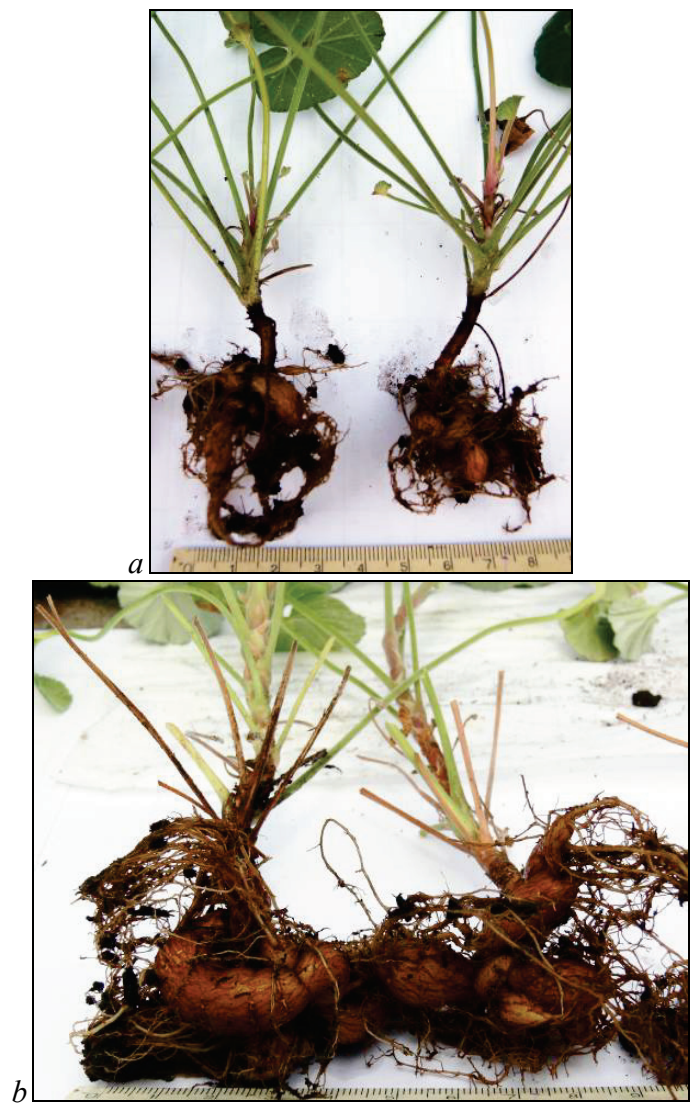

Fig. 9. Virginile stage of the development of Pelargonium sidoides: $a$ - beginning of the virginile stage, plants are 7 months old; $b-10$ month-old plants
At the age of 9 months, about $20 \%$ of the plants move to the generative period which is indicated by the appearance of flower-bearing stems. By the 11th month, all of the studied plants have entered the generative stage.

\section{Discussion}

As our observations have shown, $P$. sidoides - unlike other succulents - goes through the germinant stage rather quickly (5-7 days). To compare, for representatives of Cactaceae and Euphorbiaceae with non-succulent leaves, which fall off in the dormant period, this stage takes about 60 days (Gajdarzhi et al., 2011). The juvenile stage is the longest of those in the pre-generative period. It is the time when the plant forms a large series of leaves, which also differs this plant from the succulents. At the same time, thickened roots are formed during the second half of the juvenile and all of the virginile stage of the pregenerative period. Most likely, these are the features that allow these plants to survive the arid conditions of South Africa and to successfully compete with other plant species. It should be noted that the especially active thickening of the roots takes place during the virginile stage of development. The presence of an elongated hypocotyl part of the stem can be observed during the entire pre-generative period and may be related to formation of a litter of plant parts which have died off. The peculiarities of blossom, early transition into generative period and rather high survivability of the seeds indicate a high reproductive ability of $P$. sidoides plants in conditions of greenhouse cultivation and the potential to obtain seeds after artificial pollination.

By morphological features of leaves, pollen grain, fruits and seeds, P. sidoides is a typical representative of Pelargonium. Leaves of the studied species contain both glandular and non-glandular trichomes, similar to those of the succulent species of $P$. tetragonum and other xerophytes of the genus, which we studied (Nuzhina \& Chihman, 2009). But in general, the leaves of $P$. sidoides, by their anatomical and morphological characteristics are similar to mesophyte leaves. They differ from the latter by presence of numerous trichomes on both sides of the leaf, thin wax layer and thickened epidermis on the adaxial side - almost twice as thick as that on the abaxial side - and absence of waterbearing parenchyma, typical for most succulent plants (Nuzhyna \& Gaidarzhy, 2015). Thus, $P$. sidoides can be called a meso-xeropyhte. Dreyer \& Marais (2000), describing representatives of section Reniformia, noted the similarity in shape and morphological features of grain pollen for all representatives of the section. The comparison of pollen grain among members of other sections has shown that pollen of $P$. sidoides is much finer than that of other sections, such as $P$. endlicherianum or $P$. quercetorum, although they are similar in shape and surface topology. At the same time, surface topology of pollen grain of the close genus Geranium differs greatly (Shehata, 2008; Baser et al., 2016; 2016; Keshavarsi \& Behzadifar, 2016).

Investigation of published materials on seed morphology has shown that representatives of Pelargonium, Geranium and Erodium (Geraniaceae) genera differ in size, shape and surface topology of mericarps, while seeds of such species as Geranium purpureum, G. pyrenaicum, $G$. robertianum and E. somanum are similar in shape, but very different in surface topology and colouration (Oskay, 2017; Deniz et al., 2018). Unlike germinants of the Geranium genus, which have a large curved embryo, those of $P$. sidoides have a smaller spade-shaped embryo (Sravnitel'naya..., 2000).

\section{Conclusions}

We have studied a new specimen in the O. V. Fomin Botanical Garden's collection of succulents, a medicinal plant $-P$. sidoides, which, unlike other succulents of the genus, represented in the collection, has thickened roots. We studied the peculiarities of growth and development of the plants (duration of all development stages, leaf morphology), which allows us to state that this species, just like other representatives of the genus, has both mesomorphic and xeromorphic features and is a meso-xerophyte. The research has shown the high reproduction ability of $P$. sidoides plants in conditions of greenhouse 
cultivation. Comparative analysis of pollen, fruits and seeds $P$. sidoides has shown the relation of the species with other representatives of the genus, and in the case of fruits and seeds - with members of other genera in the family.

\section{References}

Albers, F. (2002). Pelargonium. In: Eggli, U. (Ed.). Illustrated handbook of succulent plants. Dicotiledons. Heidelberg, Springer, New York, Berlin.

Artyushenko, Z. T., \& Fedorov, A. A. (1986). Atlas po opisatel'noj morfologii vysshih rastenij. Plod [Atlas on the descriptive morphology of higher plants. Fetus]. Nauka, Leningrad (in Russian).

Barthlott, W. (1984). Microstructural features of seed surfaces. In: Current concepts in plant taxonomy. Academic Press, London. Pp. 95-105.

Baser, B., Firat, M., \& Aziret, A. (2016). The pollen morphology of Pelargonium endlicherianum and $P$. quercetorum (Geraniaceae) in Turkey. PhytoKeys, $75,153-162$.

Brendler, T., \& van Wyk, B. E. (2008). A historical, scientific and commercial perspective on the medical use of Pelargonium sidoides (Geraniaceae). Journal of Ethnopharmacology, 119, 420-433.

Carmen, G., \& Hansu, G. (2014). Antimicrobial and antifungal activity of Pelargonium roseum essential oils. Advanced Pharmaceutical Bulletin, 4, 346-349.

Deniz, I., Yildiz, K., \& Cirpici, A. (2018). Taxonomical study of seed and fruit micromorphology of the Geranium (Geraniaceae) species in the Thrace region of Turkey (Europe). Phytologia Balcanica, 24(1), 35-43.

Dreyer, L. L., \& Marais, E. M. (2000). Section Reniformia, a new section in the genus Pelargonium (Geraniaceae). South African Journal of Botany, 66(1), 44-51.

Fedorov, A. A., \& Artyushenko, Z. T. (1975). Atlas po opisatel'noj morfologii vysshih rastenij (Cvetok) [Atlas on the descriptive morphology of higher plants (Flower)]. Nauka, Leningrad (in Russian).

Gajdarzhy, M. M. (2003). Aloe, Gasteria, Havortia: Introdukciya, biologiya, ekologiya [Aloe, Gasteria, Haworthia: Introduction, biology, ecology]. Kyivskyi Universytet, Kyiv (in Ukrainian).

Gajdarzhy, M. M., Nikitina, V. V., Bahlai, K. M., \& Kalashnik, S. O. (2011). Adaptyvni stratehii sukulentnykh roslyn u preheneratyvnyi period [Adaptive strategies of succulent plants in the pregenerative period]. Vidnovlennia Porushenykh Pryrodnykh Ekosystem: Materialy IV Mizhnarodnoji Konferentsii. Tsiffovaya Tipografiya, Donetsk. Pp. 90-92 (in Ukrainian).

Gontcharova, S. B., Gontcharov, A. A., Yakubov, V. V., \& Kondo, K. (2009). Seed surface morphology in some representatives of the genus Rhodiola sect. Rhodiola (Crassulaceae) in the Russian Far East. Flora, 204, 17-24.

Ilinska, A. P., Futorna, O. A., Diachenko, I. I., \& Fedoronchuk, N. S. (2001). Vyhotovlennia preparativ vehetatyvnykh roslyn na mikrotomi-kriostati [Making of preparations of vegetative plants on a microtome-cryostat]. Ukrainian Botanical Journal, 58(2), 256-260 (in Ukrainian).

Keshavarsi, M., \& Behzadifar, M. (2016). Pollen morphology of some Geranium subgenus Robertium species of Iran. Modern Phytomorphology, 10, 39-45.

Kolodziej, H. (2011). Antimicrobial, antiviral and immunomodulatory activity studies of Pelargonium sidoides (EPs 7630) in the context of health promotion. Pharmaceuticals, 4, 1295-1314.
Matthys, H., Eisebitt, R., Seith, B., \& Heger, M. (2003). Efficacy and safety of an extract of Pelargonium sidoides (EPs7630) in adults with acute bronchitis. A randomized, double-blind, placebo-controlled trail. Phytomedicine, 10(4), 7-17.

Mayo, M., \& Van Staden, J. (2014). Medicinal properties and conservation of Pelargonium sidoides DC. Journal of Ethnopharmacology, 152(2), 243-255.

Mthiyane, P. G., Mavengahats, S., Opoku, A., \& Kleynhans, K. (2016). Morphological characterization of cultivated Pelargonium sidoides in the Northern KZN. Acta Horticulturae, 1125, 315-324.

Nuzhina, N. V., \& Chihman, O. M. (2009). Morfolohichni osoblyvosti trykhom pelarhonii [Morphological features of trichomes of pelargoniums]. Zberezhennia bioriznomanittia tropichnykh ta subtropichnykh roslyn: Materialy Mizhnarodnoi konferentsii. Kyiv. Pp. 128-132 (in Ukrainian).

Nuzhyna, N. V., \& Gaidarzhy, M. M. (2015). Comparative characteristics of anatomical and morpholjgical adaptations of plants of two subgenera Haworthia Duval to arid environmental conditions. Acta Agrobotanica, 68(1), 23-31.

Oskay, D. (2017). A morphological study on the dioeciously endemic Erodium somanum H. Pesmen (Geraniaceae), critically endangered in Turkey. Acta Botanica Croatica, 76(1), 27-31.

Pirali-Kheirabadi, K., Razzaaghi-Abyaneh, M., \& Halajian, A. (2010). Acaricidal effect of Pelargonium roseum and Eucalyptus globulis essential oils against adult stage of Rhipicephalus (Boophilus) annulabus in vitro. Veterinary Parasitology, 10, 346-349.

Raimondo, D. (2009). Red list of South African plants. Strelitzia, Pretoria

Saraswathi, J., Venkatesh, K., Baburao, N., Hilal, M. H., \& Rani, A. R. (2011). Phytopharmacological importance of Pelargonium species. Journal of Medicinal Plants Research, 5(13), 2587-2598.

Shehata, A. A. (2008). Pollen morphology of Egyptian Geraniaceae: An assessment of taxonomic value. International Journal of Botany, 4(1), 67-76.

Shellie, R. A., \& Marriott, P. J. (2003). Comprehensive two-dimensionale gas chromatography-mass spectrometry analysis of Pelargonium graveolens essential oil using rapid scanning quadrupole mass spectrometry. Analyst, 128, 879-833.

Shirokova, A. V. (2006). Pelargonii [Pelargonium]. Kladez'-Buks, Moscow (in Russian).

Shyrobokova, D. N., Nikitina, V. V., Gaidarzhy, M. M., \& Bahlai, K. M. (2003). Kaktusy ta inshi sukulentni roslyny [Cacti and other succulent plants]. Ukrainski Propilei, Kyiv (in Ukrainian).

Tahtadzhyan, A. L. (Ed.). (2000). Sravnitel'naya anatomiya semyan. Tom 6. Dvudol'nye. Rosidae II (2000) [Comparative anatomy of seeds. Vol. 6. Dicate Rosidae II]. Nauka, Saint Petersburg (in Russian).

Tokarev, P. I. (2002). Morphologiya i ultraskulptura pyltsevykh zeren [The morphology and ultrastructure of pollen grains]. Tovarischestvo Nauchnykh Izdaniy KMK, Moscow (in Russian).

Vasil'ev, B. R. (1988). Stroenie lista drevesnyih rasteniy razlichnyih klimaticheskih zon [The structure of the leaf of woody plants of different climatic zones]. LGU, Leningrad (in Russian).

Zaharevich, S. F. (1954). K metodike opisaniya epidermisa lista [On the method of describing the epidermis leaf]. Vestnik LGU, 4, 65-75 (in Russian). 